\title{
Traktat Lizboński a wspólnotowe wartości europejskie
}

\begin{abstract}
$\mathrm{W}$ DNIU 2 PAŹDZIERNIKA 2009 ROKU Unia Europejska odetchnęła z ulgą. W drugim referendum ${ }^{1}$ za ratyfikacją Traktatu z Lizbony opowiedziało się $67,1 \%$ Irlandczyków wobec 32,9\% głosów przeciwnych, przy frekwencji $58 \%{ }^{2}$. Ostatecznie wszedł on w życie 1 grudnia
\end{abstract}

\begin{abstract}
${ }^{1}$ Kontynuowanie procesu ratyfikacji w pozostałych państwach było jednym z trzech wariantów rozwiązania zaistniałej sytuacji, wraz z przeprowadzeniem ponownego referendum. Proceduralnie taka sytuacja była możliwa, czego potwierdzeniem był casus braku referendalnej ratyfikacji Traktatu z Nicei. Takie rozwiązanie, jak się okazało, wydawało się być optymalne, jednakże dość kontrowersyjne z punktu widzenia legitymacji demokratycznej. Ponadto sytuacja braku ratyfikacji dla traktatu była już w Unii znana, czego przykładem jest francuskie (29.05.2005) i holenderskie (1.06.2005) „nie” dla Traktatu ustanawiającego Konstytucję dla Europy (nt. argumentów „za” i „przeciw” zob. szerzej: Z. Czachór, Kryzys legitymizacji władzy integracyjnej. Próba przebudowy Unii Europejskiej w Traktacie ustanawiającym Konstytucję dla Europy, „Przegląd Politologiczny”, nr 4/2005, s. 67-68). W tym przypadku obrano inną drogę, mianowicie rozpoczęto prace nad nowym aktem, stanowiące de facto „dekonstytucjonalizację" (zob. J. Barcz, Zasadnicze reformy strukturalne ustroju Unii Europejskiej, [w:] Traktat z Lizbony. Gtówne reformy ustrojowe Unii Europejskiej, red. J. Barcz, Warszawa 2008, s. 59-6o.) wcześniej odrzuconego. Zob. szerzej: J. Barcz, P. Świeboda, Co dalej z Traktatem z Lizbony? Uwarunkowania strategii dla Polski, „Sprawy Międzynarodowe", nr 2/2008. Niektórzy badacze zwracają uwagę, iż brak akceptacji referendalnej spowodowany był deficytem legitymizacji: Z. Czachór, Demokracja i legitymizacja władzy UE, 27.04.2009, www.ec.europa.eu, http://ec.europa.eu/polska/news/opinie/o90427_legitymizacja_wladzy_pl.htm, 18.02.2010. Por.: T. G. Grosse, Kondycja integracji europejskiej po szczycie UE oraz referendach we Francji $i$ Holandii, „Analizy i Opinie Instytut Spraw Publicznych”, nr 39/2005, s. 4 i n., http://www.isp.org.pl/files/13001659140992203001120731274.pdf, 29.01.2010; K. Bromski, Główne przyczyny odrzucenia traktatów rewizyjnych $w$ referendach we Francji $i$ Holandii $w 2005$ oraz $w$ Irlandii $w 2008$ roku, październik 2008, www.civitaseuropae.eu, http://civitaseuropae.eu/wp-content/uploads/2008/10/glowne_przy czyny.pdf, 10.02.2010.

${ }^{2} \mathrm{~W}$ pierwszym referendum ratyfikacyjnym przeprowadzonym 12 czerwca 2008 roku, na „tak” zagłosowało 46,6\%, z kolei na „nie” oddało swój głos 53,4\% obywateli przy frekwencji 52,7\%. Zob.: Irlandzkie „tak” znów jednoczy Europę, 03.10.2009, www.tvn24.pl, http://www.tvn24.pl/12691,1622265,0,1,zielona-wyspa-powiedzialalizbonie-tak,wiadomosc.html, 25.02.2010. Na temat przyczyn absencji oraz motywów głosowania, zob. szerzej: M. Sakowicz, Referendum nad Traktatem Lizbońskim w Irlandii. Analiza politologiczna, „Rocznik Integracji Europejskiej”, nr 2/2007; a także:
\end{abstract}


2009 roku i obowiązuje na terenie całej Unii Europejskiej ${ }^{3}$.

Sprawa jego ratyfikacji wzbudzała wiele kontrowersji, a on sam często stawał się ostrym narzędziem w walce politycznej. Jednym z podnoszonych argumentów na rzecz odrzucenia Traktatu była kwestia utraty suwerenności przez Polskęe . Niewątpliwie taki apel ukierunkowany był (a pewnie i jest nadal) na osiągnięcie doraźnych, partykularnych celów politycznych, niewiele (bądź nic) mając wspólnego z tą kategorią. To właśnie możliwość ratyfikacji tegoż aktu, a wcześniej, co ważniejsze, dobrowolne przystąpienie państwa do Wspólnot i transfer swych kompetencji innym organom, na zasadzie „zlecenia”, jest niczym innym jak realizacją idei suwerenności z jednej strony", $\mathrm{z}$ drugiej natomiast, mamy do czynienia $\mathrm{z}$ integratywnym reżimem suwerenności opartym raczej o kilka suwerenności, wzajemnie się uzupełniających; od poziomu ponadnarodowego Unii Europejskiej poprzez państwo członkowskie aż do poziomu subnarodowego (regionalnego $)^{6}$. W tym kontekście, warto zaznaczyć, iż to państwa człon-

J. Barcz, P. Świeboda, Co dalej z Traktatem..., op. cit., s. 25.

${ }^{3}$ Por.: Oświadczenie rzqdowe z dnia 29 listopada 2009 r. $w$ sprawie mocy obowiazującej Traktatu z Lizbony zmieniającego Traktat o Unii Europejskiej i Traktat ustanawiający Wspólnotę Europejską, sporządzonego w Lizbonie dnia 13 grudnia 2007 r., Dz. U. 2009 Nr 203, poz. 1570. Tekst Traktatu został opublikowany w: Dz. U. Nr 203, poz. 1569.

${ }^{4}$ Jako przykład można podać epizod spalenia flagi Unii Europejskiej czy porównywanie 13 grudnia 1981 do 13 grudnia 2007. Zob. m.in. Koniec suwerenności Polski? Janusz Korwin-Mikke spalit flagę UE, 30.11.2009, www.wiadomości.gazeta.pl, http:// wiadomosci.gazeta.pl/Wiadomosci/1,80708,7316094,Koniec_suwerennosci_Polski_Janusz_Korwin_Mikke_spalil.html, 10.01.2010 czy: 13 grudnia - świętem okupanta, 15.12.2009, www.upr.pl, http://www.upr.org.pl/main/index.php?strid=1\&katid=69, 15.01.2010. Inne: W. Papis, Traktat Lizboński zagraża Polsce, 29.05.2009, www.wp.pl, http://wiadomosci.wp.pl/kat,1022309,title,Wojciech-Papis-TraktatLizbonski-zagraza-Polsce, wid,11100344, wiadomosc.html?ticaid=19b7e, 20.02.2010; Lech Kaczyński o niepodległości czyli festiwal pustych frazesów, 09.09.2009, www. prokapitalizm.pl, http://www.prokapitalizm.pl/lech-kaczynski-o-niepodleglosci-czylifestiwal-pustych-frazesow.html, 20.02.2010. Zob. także: Stanowisko Zarządu Gtównego Ligi Polskich Rodzin $w$ sprawie wejścia $w$ życie traktatu lizbońskiego, www.lpr.pl, http://www.lpr.pl/?sr=! czytaj\&id=6751\&dz=kraj\&x=0\&pocz=0\&gr=, 05.01.2010.

${ }_{5}$ Zob. szerzej: A. Wasilkowski, Uczestnictwo $w$ strukturach europejskich a suwerenność państwowa, „Państwo i Prawo”, nr 4-5/1996, s. 20 i n. Por.: S. Konopacki, Problem suwerenności w Unï Europejskiej, „Studia Europejskie” 2008, nr 3.

${ }^{6}$ Zob. szerzej: A. Gałganek, Suwerenna równość państw. Metafora zawłaszczenia (część II), „Przegląd Politologiczny” 2008, nr 1, s. 79 i n. Zob. także: A. Raczyńska, Reinterpretacja pojęcia suwerenności wobec czlonkostwa w Unii Europejskiej, „Przegląd Europejski” 2001, nr 1, s. 115 i n. 
kowskie są nadal „panami traktatów” i to w nich należy upatrywać kierunków rozwoju Unii.

Jeszcze innym zagadnieniem, które polaryzowało elity polityczne była kwestia deficytu demokratycznego i roli norm traktatowych w jego przezwyciężaniu. W opinii zwolenników ratyfikacji Traktatu, oddziałuje on w kierunku jego ograniczania, bądź też nawet jego zniwelowania. Odmiennie uważali jego przeciwnicy, prezentując pogląd, iż wejście w życie norm traktatowych spotęguje ów kryzys7.

Lena Kolarska-Bobińska tak oto relacjonowała konferencję, która odbyła się w wiosną 2007 roku w Paryżu: „(...) wszyscy referenci mówili o końcu Unii, jej rozpadzie, braku nadziei”" W związku z powyższym nasuwa się pytanie, czy rzeczywiście Unia Europejska „zdradziła” swe fundamentalne wartości demokratyczne i na tej podstawie możemy mówić o „końcu” czy nawet rozpadzie Unii?

\section{EUROPEJSKIE WARTOŚCI - DOBRY TOWAR EKSPORTOWY}

TRUDNo ISTOTE Uni EUROPEJSKIEJ określić odwołując się do dotychczasowych koncepcji z zakresu teorii państwa czy stosunków międzynarodowych, bowiem posiada ona cechy zarówno z pierwszego jak i drugiego obszaru. Powszechnie akceptowane jest podejście określające ten fenomenalny, chociażby z historycznego punktu widzenia, projekt polityczny, jako sui generis polity without politics. Jest to swego rodzaju system polityczny jednak bez polityki znanej z poziomu państw narodowych. Niemniej jednak, bez względu na to, jakiej konceptualizacji dokonamy, nie ulega wątpliwości, iż UE stara się być aktywnym aktorem stosunków międzynarodowych, co więcej, mając aspiracje, by zagrać rolę pierwszoplanową.

Spośród ról międzynarodowych Unii, R. Zięba ${ }^{9}$ wymienia m.in. rolę kulturowo-cywilizacyjną - atrakcyjnego ośrodka cywilizacyjnego

\footnotetext{
7 „Jesteśmy świadkami »wypłukiwania « narodowych instytucji pochodzących z demokratycznych wyborów” w: K. Pawłowicz, Witajcie w euroregionie polskim!, „Nasz Dziennik” z dnia 4 grudnia 2009 r. http://www.radiomaryja.pl/artykuly. php?id=101975, 10.01.2010. Natomiast V. Klaus stwierdził zaś, że: „Traktat prowadzi do pogłębienia deficytu demokracji.”, zob.: id., Traktat Lizboński: instrukcja dla początkujących, www.kapitalizm.republika.pl, http://www.kapitalizm.republika.pl/klaus_instrukcja.html, 15.01.2010.

${ }^{8}$ Deficyt demokracji w Unii Europejskiej - oczekiwania spoteczne, [w:] Deficyt demokracji w Unii Europejskiej a europejskie grupy interesów, red. U. Kurczewska, Warszawa 2008, s. 27.

9 Zob. szerzej: R. Zięba, Wstęp do polityki zagranicznej państwa, Toruń 2004, s. $244-266$.
} 
i zarazem promotora wartości kultury europejskiej. W innym ujęciu oprócz promotora multilateralizmu i współpracy międzynarodowej czy też głównego centrum handlu światowego, UE spełnia także rolę mocarstwa normatywnego, „(...) reprezentującego określony model organizacji zarówno stosunków międzynarodowych, jak i życia społecznego i politycznego wewnątrz państw. Kluczową rolę odgrywają tu wartości reprezentowane przez UE, ich oddziaływanie zależy jednak od dystansu zarówno geopolitycznego, jak i rozwojowego, który dzieli dany kraj od Europy"10. Te demokratyczne, cywilizacyjne wartości europejskie stanowią główny towar eksportowy UE (por.: art. 3.5 TUE). W zakresie promocji demokracji, swobód obywatelskich, poszanowania praw człowieka, zakazu dyskryminacji oraz demokracji uczestniczącej, UE może stać się nie tylko pionierem, ale i mocarstwem na arenie międzynarodowej ${ }^{11}$.

Rzeczywiście UE przykłada duża rolę do tychże uniwersalnych wartości. Jednak czy tak było zawsze? Otóż nie do końca ${ }^{12}$. Na podstawie analizy preambuł traktatów założycielskich oraz poszczególnych norm prawa pierwotnego, można wskazać, iż katalog wartości europejskich stanowią: bezpieczeństwo, pokój, wolność i dobrobyt. Uzupełniają go dążenie do wzrostu gospodarczego, pragnienie zrównoważonego rozwoju i zbliżenia poziomu ekonomiczno-społecznego państw członkowskich, większa stabilizacja i szybszy wzrost poziomu życia społeczeństw europejskich. Dalej dopiero, stanowiące dopełnienie tegoż zbioru - demokracja i stabilizacja polityczna ${ }^{13}$.

W zmienionej Traktatem Lizbońskim ${ }^{14}$, preambule w Traktacie o Unii Europejskiej (TUE) czytamy: „INSPIROWANI kulturowym, re-

${ }^{10}$ P. Borkowski, Tożsamość międzynarodowa UE $w$ świetle koncepcji ról międzynarodowych, „Przegląd Europejski” 2009, nr 1, s. 77-78. W opinii: J. Solany: „Unia Europejska nie jest wyspą, jest częścią globalnej wspólnoty. Dla wielu części świata słowo Europa kojarzone jest z postawą humanitaryzmu, solidarności i integracji”. Natomiast C. Rice powiada: „naszym zdaniem silna i zjednoczona Europa, która jest w stanie działać jako globalny partner Stanów Zjednoczonych wziąwszy pod uwagę wartości demokratyczne i długą historię naszych związków, przyczyni się do zwielokrotnienia sił, które walczą o demokrację, wolność i pomyślność gospodarczą na całym świecie”. Ibidem, s. $72-73$.

${ }^{11}$ Ibidem, s. 80.

${ }^{12}$ Zob. szerzej: M. Brachowicz, Dlaczego Karta Praw Podstawowych budzi sprzeciw?, „Międzynarodowy Przegląd Polityczny” 2007, nr 3, s. 6.

${ }^{13}$ J. Czaja, Europa wartości - pytania o tożsamość Unii Europejskiej, „Przegląd Europejski” 2001, nr 2, s. 29.

14 Zob.: skonsolidowane wersje TUE i TFUE: http://www.consilium.europa.eu/ showPage.aspx?id= 1296\&lang $=\mathrm{pl}$, 20, 02.2010. 
ligijnym, humanistycznym dziedzictwem Europy, z którego wynikają powszechne wartości, stanowiące nienaruszalne i niezbywalne prawa człowieka, jak również wolność, demokracja, równość oraz państwo prawne”. W dalszej części preambuły znajdujemy zapewnienie o przywiązaniu do „zasad wolności, demokracji, poszanowania praw człowieka i podstawowych wolności oraz państwa prawnego". Iście gospodarczy charakter ma z kolei preambuła do Traktatu o funkcjonowaniu Unii Europejskiej (TFUE). Jak wiadomo, preambuła nie ma mocy prawnie wiążącej, stanowi jedynie wyraz intencji ustawodawcy. Toteż, art. 2 TUE (w wersji skonsolidowanej) stanowi, iż „Unia opiera się na wartościach poszanowania godności osoby ludzkiej, wolności, demokracji, równości, państwa prawnego, jak również poszanowania praw człowieka, w tym również praw osób należących do mniejszości”. Warto tu jednak zaznaczyć, iż demokracja nie da się zadekretować na podstawie przyjęcia takiego czy innego rozwiązania normatywnego i to w postaci deklaratywnej. Ważniejszym jest praktyka funkcjonowania instytucji na podstawie i w granicach tychże rozwiązań.

Wspólne wartości europejskie, akceptowane i respektowane przez obywateli UE mogą się przyczynić do powstania europejskiego de$\operatorname{mos}^{15}$. Fakt, iż warunkiem sine qua non przystąpienia do UE jest legitymowanie się demokratycznymi rządami prawa, które można określić, jak pisze J. Markoff - „domniemaną częścią unijnego acquis communautaire" ${ }^{16}$, nie oznacza, iż w ten sposób sama konstrukcja europejska staje się demokratyczna. Unia Europejska chcąc być zatem potęgą w dziedzinie eksportu wartości demokratycznych, dla swej wiarygodności, w pierwszej kolejności winna się przyjrzeć własnych rozwiązaniom normatywnym i praktyce funkcjonowania organów; w przeciwnym wypadku będziemy mieli do czynienia z europejską hipokryzją.

\section{O DEFICYCIE DEMOKRACJI}

MówiĄc o TEJ KATEGORI niejako automatycznie nasuwa się na myśl Unia Europejska. Z całą stanowczością należy stwierdzić, iż takie rozumo-

${ }^{15}$ K. Szczerski, Cztery modele legitymizacji systemu politycznego Unii Europejskiej, [w:] Globalizacja - integracja - transformacja. Główne problemy polityczne globalizacji, integracji europejskiej oraz transformacji politycznej Europy, red. R. Bäcker, J. Marszałek - Kawa, J. Modrzyńska, Toruń 2005, s. 99.

${ }^{16}$ Cyt. za: T. Kubin, Zagadnienie „deficytu demokracji” $w$ Unii Europejskiej. Cześć I: Aspekty teoretyczne, „Studia Europejskie” 2007, nr 1, s. 12. 
wanie jest wysoce niesprawiedliwie ${ }^{17}$. Przeciwko takiemu pojmowaniu Unii i związanego z nią deficytu demokracji świadczy kilka faktów. Po pierwsze, rozbieżność pomiędzy demokracją normatywną a jej urzeczywistnieniem jest sprawą naturalną i wręcz wydawać się może nieuniknioną. „Tego, czym demokracja jest, nie można oddzielić od tego, czym być powinna. (...) Jedna definicja nie może istnieć bez drugiej, a jednocześnie nie mogą się one wzajemnie zastępować"18. Demokracja jest bowiem modelem, do którego się dąży. Po drugie, owa rozbieżność między postulatem a opisem występuje nie tylko na poziomie państw demokratycznych ${ }^{19}$, także tych skonsolidowanych ${ }^{20}$, ale również w perspektywie globalnej ${ }^{21}$. Oba przypadki są często pomijane, a „deficyt demokracji” stał się immanentną funkcją procesu integracji europejskiej. Po trzecie, funkcjonowanie demokracji zależy także od innych czynników np. kulturowych (tradycja demokratyczna), bowiem, „kontekst i konkretna sytuacja, w jakiej znajdują się społeczeństwa sprawia, że „deficyt” towarzyszy występowaniu demokracji od jej początku" 22 . Po czwarte, wskazuje się na wzrastającą absencję wyborczą oraz tendencję spadkową poziomu akceptacji dla integracji europejskiej. Wzrost absencji wyborczej dotyka zarówno członków $\mathrm{UE}^{23}$, jak i systemy polityczne będące poza nią ${ }^{24}$. Jak zauważa A. Giddens, „Nawet w dojrzałych demokracjach, które inne kraje miałyby naśladować, jest rozpowszechnione rozczarowanie demokratycznymi procedurami. Ostatnimi laty w większości krajów Zachodu zaufanie do polityków mocno spadło. Mniej ludzi idzie głosować, więcej ludzi, zwłaszcza młodych, nie jest zainteresowanych parlamentarnymi gra-

${ }^{17}$ Zob. szerzej: A. Moravcsik, Deficyt demokracji - wyolbrzymiony problem, „Nowa Europa. Przegląd Natoliński” 2005, nr 1, s. 278 - 279.

${ }^{18}$ Zob. szerzej: G. Sartori, Teoria demokracji, Warszawa 1994, s. 21 - 22.

${ }^{19}$ Zob. szerzej: M. Bankowicz, Elementy niedemokratyczne w ustrojach demokratycznych, „Politeja” 2004, nr 2, s. 325 - 334; oraz: id, Demokracja. Zasady, procedury, instytucje, Kraków 2006, s. 68 - 69, 72, 75 - 76, 78.

${ }_{20}$ Zob. szerzej: A. Antoszewski, R. Herbut, Systemy polityczne współczesnego świata, Gdańsk 2001, s. 23 i n.

${ }^{21}$ W. Aniol, Deficyt demokratyczny $w$ systemie globalnym, „Studia Europejskie” 2002, nr 4, s. $10-11$.

${ }^{22}$ T. Biernat, „Deficyt demokracji” w strukturach Unii Europejskiej, [w:] Demokracja. Teorie. Idee. Instytucje, red. T. Biernat, A. Siwik, Toruń 2001, s. 35.

${ }^{23}$ Zob. szerzej: A. Antoszewski, Partie i systemy partyjne państw Unii Europejskiej na przełomie wieków, Toruń 2009, s. 47, 49.

${ }^{24}$ Zob. szerzej: A. Antoszewski, Wzorce rywalizacji na arenie wyborczej, [w:] Systemy polityczne Europy Środkowej i Wschodniej. Perspektywa porównawcza, red. A. Antoszewski, Wrocław 2006, s. 98. 
mi” ${ }^{25}$. Same wybory z kolei można określić bardziej mianem politycznego rytuału ${ }^{26}$ niż partycypacyjnego balotażu ${ }^{27}$; natomiast relacje rządzących z rządzonymi, bardziej zbliżone są do demokracji delegatywnej $^{28}$ niż deliberatywnej ${ }^{29}$. Jeżeli pod uwagę weźmiemy poziom zadowolenia z demokracji i zaufania do instytucji politycznych, to znacznie większy problem mają Państwa Członkowskie niż Unia Europejska ${ }^{30}$. Przykładowo: 55\% Niemców, 45\% Francuzów czy 30\% Portugalczyków jest zadowolonych z demokracji; przeciętna dla zachodnioeuropejskich członków Unii wynosi $65 \%$, natomiast dla państw członkowskich z Europy Środkowej i Wschodniej - 40\%31. Biorąc pod uwagę powyższe okoliczności trudno nie zgodzić się z przywoływanym wcześniej A. Moravcsika, iż „deficyt jest w znacznym stopniu mitem” ${ }^{2}$. Unia Europejska nie jest przecież państwem, więc trudno do niej wymagać procedur znanych z poziomu narodowego, które również odstają od ideału. Być może jest tak, że tęsknimy za prawdziwie demokratycznym systemem, szukając wyjścia z sytuacji na poziomie europejskim? ${ }^{33}$. Niemniej jednak, zgadzamy się ze zwolennikami tezy o występowaniu deficytu demokracji w Unii Europejskiej.

Etapy i przebieg integracji jest znany. Warto jednak zauważyć, iż deficyt demokracji już od samego początku powstawania Wspólnot został w nie wpisany ${ }^{34}$. Mimo, iż warunkiem przystąpienia do tego procesu były demokratyczne rządy prawa, sama idea opierała się na technokratycznym modelu funkcjonowania i sprawnym rozwiązywa-

${ }^{25}$ Cyt. za: M. Bednarz, Między apatia a uczestnictwem. Dylematy wyboru, [w:] Czy upadek demokracji? Idee i wartości, red. A. Stelmach, Poznań 2007, s. 136.

${ }^{26}$ Zob. szerzej: K. Churska, Wybory jako demokratyczny rytuat polityczny, [w:] Czy upadek demokracji?..., op. cit., s. 23 i n.

${ }_{27}$ Zob. szerzej: A. Żukowski, Dylematy demokracji XXI wieku. Wybory rytualne czy balotaż partycypacyjny?, „Przegląd Politologiczny” 2005, nr 2, s. 79 i n.

${ }^{28}$ A. Antoszewski, Partie i systemy partyjne...,op. cit., s. 22 i n.

${ }^{29}$ Zob. szerzej: R. Riedel, Deliberacja - czyli na czym polega istota demokracji deliberatywnej, „Studia Polityczne” 2009, nr 23, s. 208 i n.

${ }^{30}$ Zob. szerzej: A. Łankowski, Integracja europejska $w$ świetle opinii obywateli państw czlonkowskich Unii europejskiej, [w:] Integracja europejska - nowy bariery czy trwały kryzys?, red. K. Żukrowska, Warszawa 2006, s. 137 - 145.

${ }^{31}$ Zob. szerzej: A. Antoszewski, Partie i systemy partyjne...,op. cit., s. 27 - 28, $37-38$.

${ }^{32}$ A. Moravcsik, Deficyt demokracji..., op. cit., s. 276.

${ }^{33}$ R. Riedel, Deficyt demokratyczny $w$ Unii Europejskiej. Defekt czy blogostawieństwo, „Studia Europejskie” 2008, nr 4, s. 11.

${ }^{34}$ Por. okoliczności powołania Europejskiego Banku Centralnego. Zob. szerzej: H. Gronkiewicz - Waltz, Europejska Unia Gospodarcza i Walutowa, Warszawa 2009, s. 104 i n. 
niu odtąd wspólnych problemów niż na rządach demokratycznych ${ }^{35}$. Co ciekawe, już w traktach założycielskich - Traktacie Paryskim z 18 kwietnia 1951 roku powołującym Europejską Wspólnotę Węgla i Stali (EWWiS) oraz Traktatach Rzymskich z 25 marca 1957 roku powołujących Europejską Wspólnotę Gospodarczą i Europejską Agencję Energii Atomowej (EWEA lub Euratom) - zawarta została idea kreacji Zgromadzenia Parlamentarnego (od 1962 roku Parlament Europejski) w drodze bezpośrednich wyborów, jednak ostatecznie została wcielona w życie dopiero w $1979 \mathrm{roku}^{36}$. O niedemokratycznej formule EWWiS świadczył dodatkowo fakt, iż była to organizacja stricte gospodarcza, a jako taka cech demokratycznych przejawiać przecież nie mogła. Trzon jej stanowiło wąskie grono eksperckie i elit politycznych. Podobnie, celem utworzenia EWG i EWEA nie było szerzenie demokratycznych rządów prawa mimo, iż warunkiem sine qua non przystąpienia do struktur było legitymowanie się takim właśnie reżimem ${ }^{37}$.

Kwestia „deficytu demokracji” nie była przez długi czas podejmowana. Wynikało to z faktu, iż państwa członkowskie realizowały proces integracji europejskiej na podstawie „przyzwalającego konsensusu" (permissive consensus) ich społeczeństw ${ }^{38}$. Wspólnoty czerpały swa legitymację z państw członkowskich. W miarę jednak rozszerzania ich kompetencji, kosztem organów państwowych, obywatele zaczęli odczuwać brak rzeczywistego wpływu na ich działanie ${ }^{39}$. Pierwszą próbę konceptualizacji tejże kategorii podjęła w 1972 roku Komisja Europejska w tzw. Raporcie Vedela, gdzie poruszony został temat demokracji, efektywności i zwiększenia kompetencji Parlamentu Europejskiego. Dało to początek klasycznej teorii deficytu demokracji, która opiera się na założeniu, iż transferowi kompetencji parlamentów narodowych nie towarzyszy demokratyzacja instytucji unijnych, bowiem ich uprawnienia legislacyjne nie są przekazywane do Parlamentu Europejskiego, lecz do Rady Unii Europejskiej (RUE), składającej się z przedstawicieli egzekutywy państw członkowskich ${ }^{40}$, a „(...) parla-

${ }^{35}$ K. Klaus, Pojęcie i źródło deficytu demokracji w Unii Europejskiej, „Studia Europejskie" 2004, nr 4, s. 54

${ }^{36}$ M. Kolczyński, Wybory do Parlamentu Europejskiego: partykularyzm partyjny versus wspólnotowe wartości europejskie, „Przegląd Politologiczny” 2005, nr 2, s. 98.

${ }^{37}$ Zob. szerzej: Z. J. Pietraś, Prawo wspólnotowe i integracja europejska, Lublin 2006, s. $58-60$.

${ }^{38}$ Por.: R. Riedel, Deficyt demokratyczny..., op. cit., s. 9.

${ }^{39}$ Por.: K. Klaus, Pojęcie i źródta..., op. cit., s 56 - 60.

${ }^{40}$ Zob. szerzej: K. Klaus, Pojęcie i źródła..., op. cit., s. 64. 
menty narodowe zostały zdegradowane do roli podwładnego"41. Innymi słowy powstały stan określić można jako próżnię demokracji bądź też deficyt parlamentarny ${ }^{42}$. Samej jednak kategorii „deficytu demokracji” jako pierwszy użył D. Marquand ${ }^{43}$. Wskazywał on na zbyt małą rolę PE, podając jako wyjście z sytuacji bezpośrednie wybory do tegoż organu. Pierwsze powszechne wybory do Parlamentu Europejskiego odbyły się w dniach 7-10 czerwca 1979 roku, a jego kompetencje były poszerzane wraz z kolejnymi traktami. Mimo to, Duńczycy (1992), Irlandczycy (2001, 2009), Francuzi i Holendrzy (2005) kolejnych referendach opowiadali się przeciw ratyfikacji nowych norm. Jak by tego było mało, same wybory są traktowane przez partie polityczne drugoplanowo, co nie pozostaje bez wpływu na ich postrzeganie i stosunek obywateli. Dalej idąc, euro kampania nie stanowi obszaru prezentacji ofert dotyczących wizji integracji, lecz staje się jeszcze jedną dobrą okazją do krajowej walki politycznej i to bez względu na to, w której części cyklu wyborczego odbędzie się elekcja ${ }^{44}$. Wreszcie, niektórzy autorzy zwracają uwagę na usytuowanie Europejskiego Banku Centralnego jako jeden z przejawów deficytu legitymizacji ${ }^{45}$.

Określenie, czym jest deficyt demokratyczny jest dość trudne, biorąc pod uwagę, że samo pojęcie demokracji nie jest jednoznaczne, jakby się mogło wydawać ${ }^{46}$. Będzie ono poniekąd zasadne, jeżeli punktem wyjścia uczynimy słynne Orędzie Gettysburskie wygłoszone przez A. Lincolna będą to zatem „rządy ludu, poprzez lud i dla ludu”47. Przez „rządy ludu” należy rozumieć suwerena - naród, który jest źródłem uzyskania władzy. Obecnie nie istnieje europejski demos ${ }^{48}$. „Poprzez

${ }^{41}$ R. Grzeszczak, Rola parlamentów narodowych $w$ procesach integracji europejskiej $w$ perspektywie wysiłków Unii Europejskiej $w$ przełamywaniu zjawiska deficytu demokratycznego, „Studia Europejskie” 2002, nr 1, s. 58, 60 i n.

${ }^{42}$ R. Riedel, Deficyt demokratyczny..., op. cit., s. 12.

43 Ibidem, s. 10.

${ }^{44}$ Zob. szerzej: E. Dydak, Wybory do Parlamentu europejskiego - zasady i wyniki głosowania, Warszawa 2003, s. $79-86$.

${ }_{45}$ Zob. szerzej: T. Kubin, Zagadnienie „deficytu demokracji” $w$ Unii Europejskiej. Część II: Aspekty praktyczne związane z funkcjonowaniem systemu instytucjonalnego Wspólnot Europejskich, „Studia Europejskie” 2007, nr 2, s. 22 - 28.

${ }^{46}$ Zob. szerzej: A. Antoszewski, Współczesne teorie demokracji, [w:] Studia z teorii polityki, red. A. W. Jabłoński, L. Sobkowiak, t. 2, Wrocław 1999.

47 A. Heywood, Politologia, Warszawa 2008, s. 85. Zob. szerzej: B. Banaszak, Prawo konstytucyjne, Warszawa 2001, s. 266 - 267. Por.: G. Sartori, Teoria..., op. cit., s. $52-54$.

${ }^{48}$ Nie wykształciła się także europejska opinia publiczna funkcjonująca w ramach przestrzeni europejskiego dyskursu. Podobnie jest z europejskim systemem partyjnym. 
lud”, a więc za podstawie istniejących procedur. Parlament Europejski nie spełnia funkcji ${ }^{49}$ typowych dla władzy ustawodawczej, gdyż głównym legislatorem jest Rada Europejska, niepochodząca rzecz jasna z wyborów powszechnych. Jednak jak już wcześniej wskazano problem nie wydaje się dotyczyć tylko i wyłącznie samych procedur. Dlatego też, należy raczej mówić o deficycie demokratycznej legitymizacji $^{50}$. Według D. Beethama „legitymizacja systemu nie jest dana raz na zawsze; przeciwnie jest procesem - procesem stopniowego uzyskiwania, ale i niekiedy stopniowej utraty uzasadnienia władzy" ${ }^{1}$. Na rzecz drugiej proponowanej diagnozy przemawia fakt, iż jest ona bardziej precyzyjna, a samo dążenie do zwiększenia legitymizacji wydaje się być bardziej efektywne z punktu widzenia zarówno jednostki, jak i całego systemu instytucjonalnego. Ponadto, jak już wskazano, zwiększenie procedur demokratycznych wcale nie musi prowadzić do osiągnięcia założonych celów, bowiem „demokratyczny proces wyborczy nie jest warunkiem wystarczającym dla procesu demokratycznej legitymizacji systemów politycznych. Jest to jednak warunek konieczny, bowiem władza niewywodząca się z demokratycznego procesu wyborczego nie może być we współczesnych demokracjach władzą uprawomocnioną" ${ }^{2}$.

Z legitymizacją53 mamy do czynienia na „wejściu” i „wyjściu” systemu. Ta pierwsza ma charakter wewnętrzny (input legitymacy), z kolei druga zewnętrzny (output legitymacy). Wewnętrzna legitymizacja polega na tym, iż istnieją demokratyczne procedury na podstawie, których władza uzyskuje inwestyturę do rządzenia i może w związku z tym podejmować środki władcze; innymi słowy, źródłem władzy jest wola suwerena, natomiast tak wyrażona stanowi jej uzasadnienie. W aspekcie zewnętrznym, przejawia się $\mathrm{w}$ tym, iż podejmowane działania elit są akceptowalne. „Deficyt zewnętrzny, przede wszystkim przez środki

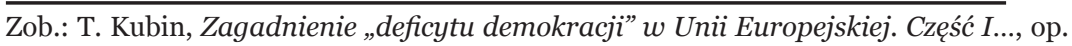
cit., s. 16.

49 Zob. szerzej: A. Antoszewski, R. Herbut, Systemy polityczne wspótczesnego..., op. cit., s. 239 i n.

${ }^{50}$ Zob. szerzej: K. Szczerski, Cztery modele..., op. cit., s. 94.

${ }^{51}$ Cyt. za: M. Żyromski, Zasady legitymizacji porządku społeczno-politycznego, „Przegląd Politologiczny” 2003, nr 2, s. 67.

$5^{2}$ P. Mikiewicz, Demokracja, wybory i legitymizacja systemu w epoce globalizacji, [w:] Czy upadek demokracji..., op. cit., s. 49.

${ }^{53}$ Zob. szerzej: J. Pawłowski, Przebudowa instytucjonalna Unii Europejskiej wobec potrzeb legitymacji, „Studia Europejskie”, nr 2/2007, s. 35 i n. Zob. także: T. G. Grosse, Europa na rozdrożu, Warszawa 2008, s. 115 i n. 
masowego przekazu, jest zazwyczaj wyolbrzymiany, wewnętrzny natomiast ignorowany" ${ }^{54}$. W dalszej części interesować nas będzie legitymizacja władzy na „wejściu” systemu Unii Europejskiej (o legitymizacji na „wyjściu” zob.: pkt. 2).

\section{INSTYTUCJONALNE ROZWIĄZANIA w TRAKTACIE LIZBOŃSKIM W PERSPEKTYWIE}

\section{PRZEZWYCIĘŻENIA DEFICYTU DEMOKRATYCZNEJ LEGITYMIZACJI}

DemoKratyczNa legitymizacja Unir Europejskiej, o czym już była mowa, nie jest prostą sumą porządków demokratycznych państw członkowskich. Na mocy, przywołanego wcześniej, art. 2 TUE, demokracja zostaje uznana za jedną z najważniejszych wartości, stanowiących fundament europejskiego projektu; zaś sama idea demokracji uzyskała nawet formalną postać ogólnej zasady prawa ${ }^{55}$.

Traktat Lizboński podpisany 13 grudnia 2007 roku w stolicy Portugalii rewidując Traktaty: o Unii Europejskiej (TUE) oraz ustawiający Wspólnotę Europejską (gdzie ten otrzymuje nazwę Traktat o funkcjonowaniu Unii Europejskiej - TFUE), w Tytule II TUE: Postanowienia o zasadach demokratycznych określa zasady ,życia demokratycznego Unii”"56. Do nich należą: 1) zasada demokratycznej równości $\left.{ }^{57} ; 2\right)$ zasada demokracji przedstawicielskiej (art. 10); 3) zasada demokracji uczestniczącej (art. 11).

Do tej pory, Parlament Europejski był sukcesywnie wzmacniany w systemie instytucjonalnym UE, wychodząc tym samym z „marginesu” procesu decyzyjnego i jednocześnie, w zamyśle architektów norm, zwiększając jej legitymizację ${ }^{58}$. Tak też czyni Traktat Lizboński, wymienić tu należy m.in. pełnienie funkcji: prawodawczej i budżetowej (wspólnie z Radą), kontroli politycznej oraz konsultacyjnej (art. 14.1. TUE). Artykuł 17 w ustępie 7 wyraża kompetencję, przy uwzględnieniu wyników wyborów do PE, wyboru przewodniczącego Komisji Europejskiej; ona sama zaś kolegialnie podlega kontroli z jego strony. Rozsze-

54 F. Emmert, M. Morawiecki, Prawo europejskie, Warszawa - Wrocław 1999, S. 170.

${ }_{55}$ C. Mik, Umocnienie legitymacji demokratycznej Unii Europejskiej, [w:] Traktat z Lizbony..., op. cit., s. 100.

${ }^{56}$ Co do zasady, dokonano recepcji norm z traktatu konstytucyjnego do tegoż tytułu, jednak zostały one „w specyficzny sposób »zdekonstytucjonalizowane «”. Zob.: J. Barcz, Zasadnicze reformy..., [w:] Traktat z Lizbony..., op. cit., s. $64-65$.

${ }^{57}$ Odnośnie zasadności takiego sformułowania zob.: C. Mik, Umocnienie legitymacji..., [w:] Traktat z Lizbony..., op. cit., s. 104.

${ }_{58}^{8}$ Zob. szerzej: R. Grzeszczak, Problem deficytu demokratycznego w strukturach wspólnotowych, „Sprawy Międzynarodowe” 2002, nr 3, s. 12 i n. 
rzono także procedurę współdecydowania na niemal wszystkie dziedziny prawa europejskiego ${ }^{59}$.

Traktat Lizboński czyni ponadto sam system polityczny bardziej przejrzystym i odpowiedzialnym; wyposażonym nie tylko w mechanizmy ochrony praw obywateli (Europejski Rzecznik Praw Obywatelskich), ale i bezpośredniej partycypacji (np. inicjatywa ludowa). Wszystkie te, jak się wydaje, kompleksowe działania mają na celu przybliżenie „Brukseli” do obywatela, będąc tym samym ukierunkowane na zmniejszenie deficytu legitymizacji ${ }^{60}$. W tym kontekście, do jednej z najbardziej istotnych zmian ustrojowych Unii zaliczyć należy rolę parlamentów narodowych ${ }^{61}$. Na podstawie art. 12 TUE: Parlamenty narodowe aktywnie przyczyniają się do prawidłowego funkcjonowania Unii:

a. otrzymując od instytucji Unii informacje oraz projekty aktów prawodawczych Unii zgodnie z Protokołem w sprawie roli parlamentów narodowych w Unii Europejskiej;

b. czuwając nad poszanowaniem zasady pomocniczości zgodnie z procedurami przewidzianymi w Protokole w sprawie stosowania zasad pomocniczości i proporcjonalności;

c. uczestnicząc, w ramach przestrzeni wolności, bezpieczeństwa i sprawiedliwości, w mechanizmach oceniających wykonanie polityk Unii w tej dziedzinie, zgodnie z artykułem 70 Traktatu o funkcjonowaniu Unii Europejskiej, oraz włączając się w polityczną kontrolę Europolu i ocenę działalności Eurojustu, zgodnie z artykułami 88 i 85 tego Traktatu;

d. uczestnicząc $\mathrm{w}$ procedurach zmiany Traktatów, zgodnie $\mathrm{z}$ artykułem 48 niniejszego Traktatu;

e. otrzymując informacje na temat wniosków o przystąpienie do Unii, zgodnie z artykułem 49 niniejszego Traktatu;

f. uczestnicząc we współpracy międzyparlamentarnej między parlamentami narodowymi i z Parlamentem Europejskim, zgodnie z Protokołem w sprawie roli parlamentów narodowych w Unii Europejskiej.

${ }^{59}$ Zob. szerzej: P. Świeboda, Polityczne znaczenie Traktatu z Lizbony i jego implementacji, [w:] Traktat z Lizbony..., op. cit., s. 293 - 294.

${ }^{60}$ Zob. szerzej: C. Mik, Umocnienie legitymacji..., [w:] Traktat z Lizbony..., op. cit., s. $104-110$.

${ }^{61}$ Por.: J. Barcz, Zasadnicze zmiany instytucjonalne, „Sprawy Międzynarodowe” 2007, $\mathrm{nr}$ 4, s. 20. 
W tym momencie warto zauważyć, iż w stosunku do postanowień traktatu konstytucyjnego, dokonano nie tylko w znaczącej mierze ich recepcji, ale i rozszerzono zawarty tam wachlarz politycznych i proceduralnych możliwości. Przybliżenie procesu decyzyjnego w systemie europejskim do obywatela, zwiększenie jego przejrzystości i odpowiedzialności organów uczyni Unię Europejską bardziej legitymizowaną. Biorąc pod uwagę ów proces, „(...) wertykalna dystrybucja władzy przeplata się z tu z horyzontalną redystrybucją. (...) Podstawą dla transferu kompetencji jest realizacja zasady subsydiarności, która zakłada, że każda dziedzina Wspólnot otrzymuje tyle uprawnień władczych, ile potrzebuje, aby rozwiązać problemy, z którymi z racji ich rozmiarów czy natury można najlepiej poradzić sobie na poziomie wspólnotowym"62. Innymi słowy, istotą tej zasady jest podejmowanie decyzji na możliwie jak najniższym szczeblu; dopiero wtedy, gdy jest to niemożliwe zachodzi swego rodzaju „subdelegacja” uprawnień. To właśnie parlamenty narodowe, poprzez „włączenie” ich do systemu instytucjonalnego sensu largo zostały uprawnione do badania zgodności projektów aktów prawa unijnego z zasadą subsydiarności; jest to zatem uprawnienie kontrolne, monitorujące, ale i quasi-ustawodawcze ${ }^{63}$.

Oprócz już wspomnianych regulacji, pozycję krajowych legislatyw w porządku polizbońskim określają także: Protokół nr 1: W sprawie roli parlamentów narodowych $w$ Unii Europejskiej; on zaś pozostaje w ścisłym związku z Protokołem nr 2: $w$ sprawie stosowania zasad pomocniczości i proporcjonalności. Oba, ale i także wiele innych, zostały załączone do Traktatu Lizbońskiego.

Zgodnie z Protokołem nr 1, „Dokumenty konsultacyjne Komisji (zielone księgi, białe księgi i komunikaty) są przekazywane, po ich opublikowaniu, parlamentom narodowym bezpośrednio przez Komisję. Komisja przekazuje również parlamentom narodowym roczny program prac legislacyjnych oraz wszelkie inne dokumenty dotyczące planowania legislacyjnego lub strategii politycznej równocześnie z ich przekazaniem Parlamentowi Europejskiemu i Radzie" (art. 1); dotyczy to również projektów aktów prawodawczych ${ }^{64}$, a obowiązek prze-

${ }^{62}$ Z. Czachór, Parlament państwa członkowskiego Unii Europejskiej a badanie zgodności projektów aktów prawa wspólnotowego z zasadą subsydiarności, „Studia Europejskie" 2006, nr 1, s. 42, 43. Por.: F. Emmert, M. Morawiecki, Prawo..., op. cit., s. 151. Szerzej na temat zasady subsydiarności zob.: Z. J. Pietraś, Prawo wspólnotowe...,op. cit., s. 113 i n. Definicję traktatową wyraża art. 5.3 TUE.

${ }^{63}$ Ibidem, s. 45, 48.

${ }^{64}$ Art. 2 Protokołu nr 1 stanowi: „(...) przez „projekty aktów prawodawczych” rozu- 
kazania ich do krajowych ciał ustawodawczych spoczywa na instytucjach, o których te pochodzą (wystąpily z inicjatywą), z pewnymi wyjątkami (zob. art. 2). Ciałom tym, ponadto, przekazywane są porządki obrad, wyniki i protokoły z posiedzeń Rady, równocześnie z przekazaniem tychże dokumentów rządom Państw Członkowskich (art. 5); także „Trybunał Obrachunkowy przekazuje swoje sprawozdanie roczne parlamentom narodowym w celach informacyjnych, równocześnie z przekazaniem go Parlamentowi Europejskiemu i Radzie” (art. 7). Po otrzymaniu „projektów aktów prawodawczych” parlament ma ośmiu tygodniu za zapoznanie się z dokumentem. Przyjmuje on uzasadnione opinie, stwierdzające niezgodność z zasadą subsydiarności. Nie wgłębiając się w procedurę ${ }^{65}$, należy zauważyć, iż już na etapie przedkładania projektu aktu, krajowy ustawodawca uzyskuje prawo weta suspensywnego ${ }^{66}$, bowiem jeżeli liczba uzasadnionych opinii stanowi co najmniej jedną trzecią liczby głosów przyznanych parlamentom, to wtedy dany projekt zostaje: 1) ponownie rozpatrywany; 2) zmieniony; bądź 3) wycofany. Mimo, iż parlamenty narodowe otrzymują jedynie możliwość skorzystania z tzw. „żółtej kartki”, to na podstawie innych norm traktatowych Państwa Członkowskie mogą skuteczniej blokować podjęcie decyzji ${ }^{67}$. Wreszcie, parlamenty narodowe będą mogły inicjować wniesienie skargi przez państwo członkowskie do w sprawie naruszenia przez dany akt zasady pomocniczości (por.: art. 8 Protokołu nr 2). Ponadto, rozszerzony został mechanizm współpracy parlamentarnej, a one same są uprawione do kontroli tzw. procedury kładki i klauzuli elastyczności oraz innych środków politycznych ${ }^{68}$.

Unia Europejska jest unikalnym w skali światowej projektem politycznym. Projektem, którego spoiwem są nie tylko interesy (bez względu na to, czy zdefiniujemy je jako partykularne bądź wspólne), ale i wyznawane wartości cywilizacyjne i kulturowe. Projektem, który nie będąc państwem, jednocześnie dąży do upodmiotowienia swojego obywatela (podkr. M. B.) w postaci zasady subsydiarności, zapewniając mu, na tyle ile jest to możliwe, szeroki zakres czynnego włączenia

mie się wnioski Komisji, inicjatywy grupy Państw Członkowskich, inicjatywy Parlamentu Europejskiego, wnioski Trybunału Sprawiedliwości, zalecenia Europejskiego Banku Centralnego i wnioski Europejskiego Banku Inwestycyjnego mające na celu przyjęcie aktu prawodawczego"

${ }_{65}$ Zob. szerzej: J. Barcz, Zasadnicze reformy...,op. cit., s. 68 - 69.

${ }^{66}$ C. Mik, Umocnienie legitymacji..., op. cit., s. 109.

${ }^{67}$ Zob. szerzej: J. Barcz, Zasadnicze zmiany...,op. cit., s. $20-21$.

${ }^{68}$ Zob. szerzej: J. Barcz, Zasadnicze reformy..., op. cit., s. $69-70$. 
się w życie Wspólnoty; chroniąc jego praw za pomocą odpowiedniego zabezpieczenia normatywnego i instytucjonalnego. Projektem, którego celem nie jest „pacyfikacja” państw narodowych, lecz ich większe wzmocnienie, nadając im nowy funkcjonalny wymiar; jednym z nich jest właśnie zwiększenie roli parlamentów narodowych, wspomagany dodatkowo zasadą równowagi instytucjonalnej - za pomocą mechanizmu „hamulców i równoważników” (cheecks and balances). Projektem, ukierunkowanym na deliberację, a nie majoryzację. Pomimo to, niektóre rozwiązania Traktatu Lizbońskiego w interesującej nas materii, należy ocenić krytycznie ${ }^{69}$. Niemniej, niewątpliwie przyczynią się one do zwiększenia legitymizacji demokratycznej na „wejściu” do systemu Unii Europejskiej. Czas pokaże, w jakiej mierze przełoży się to na jej aspekt „wyjściowy”. Nawiązując do wcześniej postawionego pytania, biorąc pod uwagę powyższe konstatacje, można stwierdzić, iż właśnie teraz można oczekiwać integracji z prawdziwego zdarzenia. Wiele zależy tu jednak od elit politycznych (a tu można mieć pewne oba$w^{70}$ ) i nas samych. Pytaniem otwartym pozostaje czy będziemy potrafili skorzystać z tego dziejowego dobrodziejstwa.

\section{SUMMARY}

AN ISSUE raised more and more frequently in political, as well as scientific discourse in the context of the European Union, is "democratic deficit". At the time, EU is perceived as an institution guaranteeing the preservation of democratic values in Europe and promoting them both on the continent and beyond. This article discusses both points of view, with emphasis placed on the democratic deficit aspect, measures undertaken to eliminate the negative consequences of the process, as well as the history of the concept: starting from the single European Act, through general elections to the European Parliament, and formal solutions leading to the gradual increase of EU powers. It is assumed in the article that the problem of democratic deficit has persisted in the European Union, especially since several changes were introduced to the political system of EU after The Treaty of Lisbon. As result, the key question that must be answered is whether under the provisions of the Treaty the EU will strengthen its democratic legitimacy.

${ }^{69}$ Ibidem, s. 70.

${ }^{70}$ Zob. szerzej: Z. Czachór, Parlament państwa..., op. cit., s. 55 - 56, a także: P. Świeboda, Polityczne znaczenie..., op. cit., s. 295. 
This article attempts to provide an answer, analyzing the role of national parliaments in the new institutional and normative reality and in the context of the democratic legitimacy deficit.

\section{Nota O AUTORZE}

Maciej Banaszak [banaszak_maciej@poczta.fm] - absolwent politologii, specjalność administracja europejska; obecnie kontynuuje studia na tym samym kierunku (specjalność: administracja samorządowa). Jego zainteresowania badawcze koncentrują się wokół systemów politycznych, ze szczególnym uwzględnieniem systemów partyjnych i wyborczych oraz ich wzajemnej relacji. Aktualnie pełni funkcję sekretarza Koła Naukowego Samorządu Terytorialnego. 